\author{
Нікішина О.В. \\ доктор економічних наук, старший науковий співробітник \\ відділ ринкових механізмів та структур \\ Інститут проблем ринку та економіко-екологічних досліджень НАН України \\ Французький бульвар, 29, м. Одеса, Україна, 65044 \\ E-mail:ksenkych@gmail.com
}

\title{
МЕТОДИЧНИЙ ПІДХІД ДО ЦІНОВОГО МОНІТОРИНГУ ТОВАРНОГО РИНКУ (НА ПРИКЛАДІ РИНКУ ХЛІБОПРОДУКТІВ)
}

Обґрунтовано методологічний підхід до цінового моніторингу товарного ринку, що поєднав концептуальний і методичний базиси, циклічну природу системи цінового моніторингу та її складові. Запропоновано методичний підхід до цінового моніторингу ринку з акцентом на оціночний базис у розрізі головних напрямів моніторингу, які мають специфічні складові та оцінюються за допомогою множини аналітичних показників, у т.ч. інноваційних. Проведено контурний ціновий моніторинг вітчизняного ринку хлібопродуктів, який довів прикладну значимість нових цінових показників та методик аналізу (зокрема, цінового логістичного балансу, коефіцієнтів дискримінаційності цін) і дозволив визначити низку закономірностей і співвідношень, врахування яких у регуляторних заходах держави покликано підвищити їх ефективність.

Ключові слова: ціновий моніторинг та аналіз, вертикально суміжні ринки, логістичний ланцюг, ринок хлібопродуктів, селективні регуляторні заходи.

This work is licensed under a Creative Commons Attribution 4.0 International License http://creativecommons.org/licenses/by/4.0/

Постановка проблеми та їі зв'язок 3 важливими науковими та практичними завданнями В умовах транзитивної економіки об'єктивно виникає необхідність у нових підходах до збору, обробки, аналізу економічної інформації про мінливі у часі складні багаторівневі ринкові системи. У світовій практиці такі підходи реалізуються шляхом постійного та організаційно ефективного цінового моніторингу (далі - ЦМ) товарних ринків. Питання цінового аналізу економічних систем різних рівнів займає вагоме місце в розвитку аналітичної думки, адже цінові показники визначають ефективність їх функціонування. Об'єктивний ЦМ товарного ринку формує аналітичний фундамент для прийняття науково обгрунтованих управлінських рішень щодо напрямів $\mathrm{i}$ методів державного регулювання, застосування заходів антимонопольного законодавства, прогнозування кон'юнктури ринку тощо. Існування багатьох підходів до методичного забезпечення цінового моніторингу ринкових систем обумовлює необхідність наукового пошуку в напрямі їх систематизації та інноваційного розвитку.

Аналіз останніх публікацій по проблемі. Проблема методичного забезпечення цінового аналізу товарних ринків багатопланова й багатоаспектна, їі зміст розкрито у наукових працях Бутенка А. I., Кучеренка В. Р. [1], Дем'яненка М. Я. [2], Осташко Т. О., Точиліна В. О. [3], Павленка А. Ф. [4], Савицької Г. В. [5], Глущенка К. П. [6] та інших учених. Водночас недостатньо дослідженими залишаються питання теоретико-методологічного забезпечення ЦМ товарних рин- ків, систематизації головних напрямів моніторингу та сукупності аналітичних показників, розробки нових цінових показників та нових методик аналізу, що дозволяють здійснювати міжринкові порівняння за етапами логістичного ланцюга, визначати латентні тенденції та цінові співвідношення.

Ці обставини обумовили мету і завдання даної статті.

Формулювання цілей дослідження. Мета статті - розробка методичного підходу до цінового моніторингу товарного ринку та його апробація на прикладі українського ринку хлібопродуктів - окреслила низку завдань:

- визначення структури та циклічної природи системи цінового моніторингу, інтерпретація терміну;

- $\quad$ обгрунтування методологічного підходу до ЦМ товарного ринку у двоєдності концептуального та методичного базисів;

- обгрунтування напрямів ЦМ та множини аналітичних показників;

- проведення контурного цінового моніторингу ринку хлібопродуктів для апробації напрямів моніторингу, що мають інноваційну спрямованість.

Виклад основних результатів та їх обгрунтування. Термін «моніторинг» (від англ. monitoring) енциклопедичні ресурси інтерпретують як постійне спостереження за досліджуваним об'єктом, явищем або процесом 3 метою визначення їх відповідності або невідповідності бажаному результату [7]. Ціновий моніторинг $є$ важливою складовою загального 
моніторингу товарного ринку. Ціновий моніторинг інтерпретуємо як систему збору даних, розрахунку та аналізу цінових показників релевантного та вертикально суміжних ринків, яка дозволяє систематично фіксувати та оцінювати цінові характеристики ринків, а також чинники, що їх визначають. Ціновий моніторинг дозволяє розробляти пропозиції щодо розвитку товарного ринку в певному напрямі у відповідності до пріоритетів державної політики на певному етапі економічного розвитку, а також визначати ефективність управлінських заходів.

Методологічний підхід до цінового моніторингу товарного ринку, що пропонується автором та $\epsilon$ результатом багаторічних досліджень [8, 9, 10 ], поєднує концептуальний та методичний базиси, складові яких наведено на рис. 1.

\begin{tabular}{|c|c|c|}
\hline & Кониептуальвний & a 3 uc \\
\hline & ета изінового моніторингу то & арного ринку 口 \\
\hline $\begin{array}{l}\text { 1. Систематичний збір та с } \\
\text { теристики релевантного р } \\
\text { нього ринків як основи пр } \\
\text { рішень для забезпечення е } \\
\text { ринків (економічна скла }\end{array}$ & $\begin{array}{l}\text { ліз інформації про цінові харак- } \\
\text { ку та вертикально суміжних до } \\
\text { няття виважених управлінських } \\
\text { ктивного функціонування даних } \\
\text { ва) }\end{array}$ & $\begin{array}{l}\text { 2. Постійне спостереження за динамі- } \\
\text { кою змін доходів населення та цінами } \\
\text { на соціально значимі види товарів для } \\
\text { своєчасного коригування державної } \\
\text { політики ціноутворення } \\
(\text { сочіальна складова) }\end{array}$ \\
\hline & ання ціновового моніторингу п & оварного ринку п \\
\hline $\begin{array}{l}\text { 1. Систематизація інформа } \\
\text { 2. Кількісна й якісна оцінг } \\
\text { множини різноаспектних к } \\
\text { 3. Оперативне виявлення г } \\
\text { ринків } \\
\text { 4. Прогнозування розвитку } \\
\text { 5. Узагальнення результаті }\end{array}$ & $\begin{array}{l}\text { Iних потоків у розрізі головних на } \\
\text { дінової динаміки на релевантном } \\
\text { геріїв } \\
\text { दтивних тенденцій та цінових дед } \\
\text { оцесів і цінових співвідношень у } \\
\text { оніторингу як база для прийнятт }\end{array}$ & $\begin{array}{l}\text { ппямів моніторингу } \\
\text { у та суміжному ринках із використанням } \\
\text { ормацій у системі вертикально суміжних } \\
\text { секторах товарного ринку } \\
\text { управлінських рішень }\end{array}$ \\
\hline & иичпи иінового моніторингу & \\
\hline $\begin{array}{l}\text { 1.Пріоритетність еконо- } \\
\text { мічних інтересів держави } \\
\text { як носія інтересів суспіль- } \\
\text { ства }\end{array}$ & $\begin{array}{l}\text { Оцінка цінових параметрів і спіє } \\
\text { шньому та зовнішньому вимірі з } \\
\text { інтересів окремих суб’єктів ринг } \\
\text { і в прийнятті управлінських ріш }\end{array}$ & $\begin{array}{l}\text { відношень на товарному ринку у внутрі- } \\
\text { дійснюється не з позиції економічних } \\
\text { су, а держави; даний принцип є головним } \\
\text { ень }\end{array}$ \\
\hline $\begin{array}{l}\text { 2. Системність і комплек- } \\
\text { сність }\end{array}$ & $\begin{array}{l}\text { Моніторинг товарного ринку як } \\
\text { з урахуванням всіх внутрішніх і } \\
\text { торами ринку) та їх взаємозалеж } \\
\text { ня причинних залежностей у рел }\end{array}$ & $\begin{array}{l}\text { складної динамічної системи проводиться } \\
\text { зовнішніх зв’язків між елементами (сек- } \\
\text { ності, забезпечуючи всебічне досліджен- } \\
\text { евантній системі }\end{array}$ \\
\hline $\begin{array}{l}\text { 3.Oперативність і гнуч- } \\
\text { кість }\end{array}$ & $\begin{array}{l}\text { Здатність швидкого проведення } \\
\text { управлінських рішень, швидкогс } \\
\text { ньому і внутрішньому економічя }\end{array}$ & $\begin{array}{l}\text { моніторингу та оперативного прийняття } \\
\text { реагування та врахування змін у зовніш- } \\
\text { оому просторі }\end{array}$ \\
\hline $\begin{array}{l}\text { 4.Об'єктивність і точ- } \\
\text { ність }\end{array}$ & $\begin{array}{l}\text { Інформаційна база для монітори } \\
\text { результати обгрунтовуватися то }\end{array}$ & $\begin{array}{l}\text { нгу повинна бути достовірною, а його } \\
\text { нними аналітичними розрахунками }\end{array}$ \\
\hline 5. Ефективність & $\begin{array}{l}\text { Моніторинг повинен активно вп } \\
\text { визначати цінові деформації на } \\
\text { прийняття регуляторних заходів } \\
\text { ки зворотної реакції ринку на за }\end{array}$ & $\begin{array}{l}\text { ливати на цінову ситуацію, своєчасно } \\
\text { оварних ринках та слугувати базою для } \\
\text { щодо їх нівелювання (зменшення), оцін- } \\
\text { ходи державного впливу }\end{array}$ \\
\hline 6. Цілеспрямованість & $\begin{array}{l}\text { Цільовий моніторинг селективнl } \\
\text { сі, які є джерелом цінової нестаб }\end{array}$ & $\begin{array}{l}\text { Iх «розривів» у відтворювальному проце- } \\
\text { ільності або деформацій на ринку }\end{array}$ \\
\hline 7. Науковість & $\begin{array}{l}\text { Постійне удосконалення методи } \\
\text { дового світового досвіду моніто }\end{array}$ & $\begin{array}{l}\text { к цінового аналізу та використання пере- } \\
\text { оннгу товарних ринків }\end{array}$ \\
\hline & 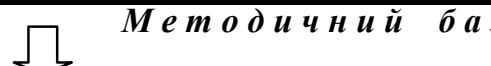 & $\begin{array}{ll}u c & \square\end{array}$ \\
\hline $\begin{array}{l}\text { Методичні положення ųiң } \\
\text { відношень у системі верти } \\
\text { жавного цінового регулюв }\end{array}$ & го моніторингу товарного ринк & $\begin{array}{l}\text { y: аналіз цінової динаміки, цінових спів- } \\
\text { азників цінової еластичності, впливу дер- } \\
\text { діагностика релевантного ринку }\end{array}$ \\
\hline Пріоритети національно & $\begin{array}{l}\text { літики в ринковому вимірі, страл } \\
\text { ку товарних ринків в умовах відк }\end{array}$ & $\begin{array}{l}\text { пегічні орієнтири відтворювального роз- } \\
\text { ритої економіки }\end{array}$ \\
\hline $\begin{array}{l}\text { 1. Нормативно-правові } \\
\text { 2. Фінансово-економічні }\end{array}$ & 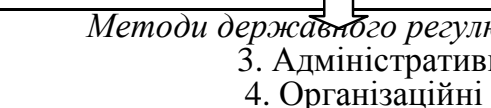 & овання \\
\hline $\begin{array}{l}\text { Методичні положення ои } \\
\text { ктів впровадження регул } \\
\text { них заходів }\end{array}$ & $\begin{array}{l}\text { рективності регулювання: оцің } \\
\text { x заходів держави, вибір найе }\end{array}$ & $\begin{array}{l}\text { ка відтворювального та податкового ефе- } \\
\text { рективнішого із сукупності альтернатив- }\end{array}$ \\
\hline
\end{tabular}

Рис. 1. Структурна схема методологічного підходу до цінового моніторингу товарного ринку [авторська розробка] 
Головною метою цінового моніторингу товарного ринку є постійний збір та аналіз інформації про цінові характеристики як релевантного ринку, так і вертикально суміжних до нього ринків, як бази прийняття управлінських рішень для ефективного функціонування даних ринків. Для соціально значимих товарних ринків доцільним є фокусування уваги на соціальному аспекті цінового моніторингу, хоча він, беззаперечно, входить до складу економічної компоненти головної мети моніторингу (див. рис. 1). Серед виділених п’яти основних завдань цінового моніторингу центральне місце належить кількісному та якісному аналізу цінових характеристик досліджуваних ринків, результати якого дозволяють ідентифікувати негативні тенденції й цінові деформації у системі та обгрунтувати напрями селективного впливу держави.

Невід'ємною складовою методологічного підходу є принциии цінового моніторингу товарного ринку, до складу яких автором віднесено наступні (див. рис. 1): (1) пріоритетність економічних інтересів держави як носія інтересів суспільства; (2) системність і комплексність; (3) оперативність і гнучкість; (4) об' єктивність і точність;
(5) ефективність;

(6) цілеспрямованість; (7) науковість. Виділені принципи орієнтують вектор моніторингу на оцінку цінової ситуації з позиції ефективного функціонування товарного ринку, реалізації економічних інтересів держави та цільового впровадження регуляторних заходів для зменшення цінових деформацій на ринку.

Методичний базис включає методичні положення цінового моніторингу товарного ринку, цінову діагностику як основу для прийняття управлінських рішень щодо методів і заходів регулювання, узгоджених із пріоритетами державної політики й стратегічними напрямами розвитку релевантного ринку, а також методичні положення оцінки ефективності регуляторних заходів (див. рис. 1). На погляд автора, ціновий моніторинг товарного ринку є циклічним процесом, представленим «колообігом» шістьох складових, що змінюються в залежності від мети й завдань моніторингу та контролюються державою, яка коригує методи й регуляторні заходи для забезпечення їх ефективності та позитивної зворотної реакції ринку на зовнішній вплив (рис. 2).

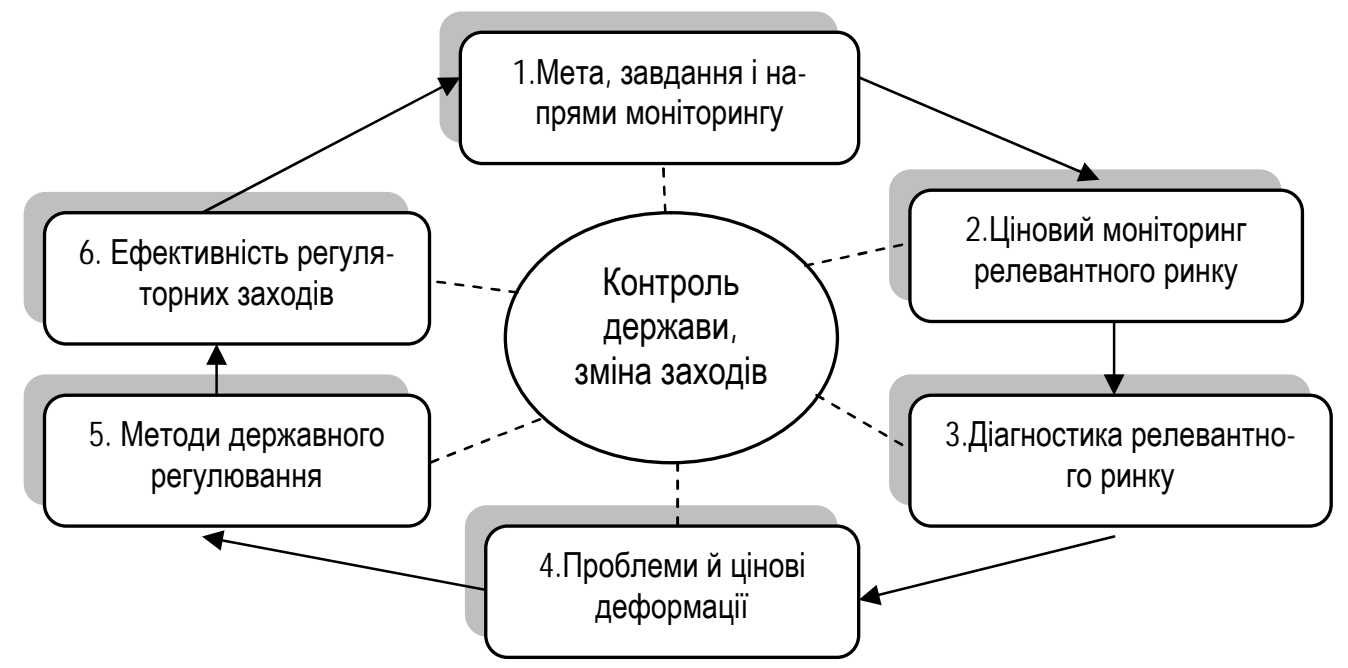

Рис. 2. Циклічність процесу цінового моніторингу товарного ринку [авторська розробка]

Методичні положення цінового моніторингу товарного ринку розглянемо більш детально (рис. 3). Першим етапом ЦМ, як і загального моніторингу, є ідентифікація релевантного ринку. Другий етап включає безпосередньо процес цінового моніторингу ринку із використанням системи показників, який може здійснюватися (у залежності від мети) за одним або декількома напрямами, а саме: (1) аналіз цінової динаміки; (2) аналіз цінових співвідношень; (3) аналіз показників цінової еластичності; (4) аналіз впливу державного цінового регулювання на процеси відтворення ринку. Кожний виділений напрям ЦМ має специфічні складові (зокрема, внутрішню і зовнішню), що оцінюються за допомогою певних показників та методик аналізу. Так, аналіз цінової динаміки на товарному ринку може здійснюватися у часовому, регіональному та суб'єктному розрізах із використанням абсолютних і відносин значень цін, базових і ланцюгових індексів цін (реалізаційних і споживчих), індексу цінової конкуренції, що є свідченням багаторівневості ЦМ.

Другий напрям ЦМ - аналіз цінових співвідношень - запропоновано автором здійснювати як у мезосистемі вертикально суміжних ринків (внутрішній вимір), так і в макроекономічній системі (зовнішній вимір). При цьому запропоновано використання нових методик цінового аналізу, що дозволяють глибше оцінити природу цінових співвідношень, зокрема, розрахунок цінового логістичного балансу, коефіцієнтів дискримінаційності цін (див. рис. 3). Аналіз показників цінової еластичності теж має внутрішню (коефіцієнти еластичності внутрішнього попиту й пропозиції) та зовнішню складові (коефіцієнти еластичності зовнішнього попиту й перехресної еластич- 
ності). Четвертий напрям ЦМ орієнтований на оцінку зворотної реакції ринку (наприклад, приріст доданої вартості товару) на зовнішній вплив і $є$ індикатором результативності регуляторних методів і заходів держави. У числі нових показників для оцінки глибини регуляторного впливу слід виділити коефіцієнт податкової еластичності, який показує відсоткову зміну обсягів податків від ринкових суб'єктів при зміні доданої вартості на $1 \%$ [8, с. 238].

\begin{tabular}{|c|c|c|c|}
\hline \multicolumn{4}{|c|}{$\begin{array}{l}\text { 1. Ідентифікація релевантного товарного ринку: товарні, територіальні та часові межі ринку, ємність, стру- } \\
\text { ктура та головні суб'єкти досліджуваного ринку } \\
\text { 2. Головні напрями цінового моніторингу релевантного ринку та система аналітичних показників }\end{array}$} \\
\hline 2.1. Аналіз цінової динаміки & $\begin{array}{l}\text { Часовий розріз: місяці } \\
\text { років, ряди динаміки } \\
\text { Регіональний розріз: за } \\
\text { йонами, містами) держағ } \\
\text { Суб'єктний розріз: за } \\
\text { подарювання (великим } \\
\text { малими; різних форм вл: }\end{array}$ & $\begin{array}{l}\text { року, декілька } \\
\text { регіонами (ра- } \\
\text { у } \\
\text { уб' єктами гос- } \\
\text { и, середніми, } \\
\text { сності тощо) }\end{array}$ & $\begin{array}{l}\text { Показники: } \\
\text { Абсолютні й відносні значення } \\
\text { цін; базові та ланцюгові індекси } \\
\text { цін реалізації товарів (споживчих } \\
\text { цін); індекс цінової конкуренції. }\end{array}$ \\
\hline \multirow[t]{2}{*}{$\begin{array}{l}\text { 2.2. Аналіз цінових співвід- } \\
\text { ношень }\end{array}$} & $\begin{array}{l}\text { Внутрішній вимір: у } \\
\text { системі вертикально } \\
\text { суміжних ринків (мезо- } \\
\text { система) }\end{array}$ & \multicolumn{2}{|c|}{$\begin{array}{l}\text { Показники: } \\
\text { Співвідношення темпів росту (зниження) цін, со- } \\
\text { бівартості та рентабельності товарів за етапами } \\
\text { логістичного ланцюга; ціновий логістичний ба- } \\
\text { ланс }\end{array}$} \\
\hline & $\begin{array}{l}\text { Зовнішній вимір: у мак- } \\
\text { роекономічній системі }\end{array}$ & \multicolumn{2}{|c|}{$\begin{array}{l}\text { Показники: } \\
\text { Коефіцієнт дискримінаційності внутрішніх цін } \\
\text { Коефіцієнт дискримінаційності експортних цін }\end{array}$} \\
\hline $\begin{array}{l}\text { 2.3. Аналіз показників цінової } \\
\text { еластичності }\end{array}$ & $\begin{array}{l}\text { Внутрішній вимір: } \\
\text { у межах внутрішнього } \\
\text { релевантного ринку }\end{array}$ & \multicolumn{2}{|c|}{$\begin{array}{l}\text { Показники: } \\
\text { Коефіцієнт цінової еластичності внутрішнього } \\
\text { попиту на товар релевантного ринку } \\
\text { Коефіцієнт цінової еластичності пропозиції } \\
\text { Коефіцієнт цінової еластичності за доходами на- } \\
\text { селення }\end{array}$} \\
\hline & $\begin{array}{l}\text { Зовнішній вимір: } \\
\text { у межах макросистеми }\end{array}$ & \multicolumn{2}{|c|}{$\begin{array}{l}\text { Коефіцієнт цінової еластичності зовнішнього по- } \\
\text { питу на товар релевантного ринку } \\
\text { Коефіцієнт перехресної еластичності }\end{array}$} \\
\hline $\begin{array}{l}\text { 2.4. Аналіз впливу державного } \\
\text { цінового регулювання на про- } \\
\text { цеси відтворення ринку }\end{array}$ & \multicolumn{3}{|c|}{$\begin{array}{l}\text { Показники: } \\
\text { Співвідношення рівня ринкових і державних регульованих цін } \\
\text { Взаємозв'язок динаміки змін цін та доданої вартості товару } \\
\text { Коефіцієнт еластичності податків за доданою вартістю товару }\end{array}$} \\
\hline
\end{tabular}

3. Цінова діагностика релевантного ринку: якісний аналіз причинно-наслідкових зв'язків, що визначають цінову ситуацію на ринку; прогнозні сценарії розвитку релевантного та вертикально суміжних до нього ринків 4. Вибір методів і заходів державного селективного регулювання, оцінка ефективності регуляторних заходів

Рис. 3. Оціночна складова методичних положень цінового моніторингу товарного ринку [авторська розробка]

Третій етап ЦМ - цінова діагностика - передбачає більш високий рівень аналізу причиннонаслідкових зв'язків, що визначають цінову ситуацію на ринку. Результати якісного аналізу формують аналітичну базу для моделювання прогнозних сценаріїв розвитку релевантного та вертикально суміжних до нього ринків, які, в свою чергу, визначають вибір методів і заходів селективного регулювання у межах четвертого етапу ЦМ (див. рис. 3).

Система цінового моніторингу включає в себе функціонування чотирьох забезпечуючих підсистем, а саме: інформаційної, методичної, організаційної та технічної. Обсяги та склад інформаційної підсистеми визначають коло аналітичних показників та глибину ЦМ товарного ринку; при іiі формуванні ва- жливим є дотримання принципу об'єктивності й точності даних. Структура організаційної й технічної підсистем залежить від того, який саме державний орган буде займатися вивченням і прогнозуванням цінових характеристик ринків. В ході організації роботи даних підсистем важливо дотримуватися принципів системності й комплексності, оперативності й гнучкості, а також забезпечити передачу інформації від одного структурного підрозділу до іншого для прийняття своєчасних та оптимальних управлінських рішень. Структура методичної підсистеми представлена автором на рис. 3. Для перевірки ії практичної значимості та емпіричної результативності проведемо контурний ЦМ стратегічного ринку хлібопродуктів, акцентувавши увагу на інноваційних методиках ціно- 
вого аналізу з дотриманням принципів цілеспрямованості та науковості. Розпочнемо з оцінки цзінового логістичного балансу як складової другого напряму ЦМ - аналізу цінових співвідношень у внутрішньому вимірі.

Особливістю цінового логістичного балансу (таблиця 1) є аналіз як абсолютних показників середніх цін у логістичному ланцюгу «пшениця - борошно пшеничне - хлібопродукти», так і цінових індексів (ланцюгових і базових) та відносних показників порівняно із ціною борошна. Такий методичний підхід до багаторівневого аналізу, закладений в фундамент логістичного цінового балансу, дозволяє визначити ступінь впливу вартості продукції нижньосуміжного ринку на ціну продукції верхньосуміжних ринків у їх динамічній відтворювальній системі.

Таблиця 1

Ціновий логістичний баланс на українському ринку хлібопродуктів, грн./т*

\begin{tabular}{|c|c|c|c|c|c|c|c|c|c|c|}
\hline \multirow[t]{2}{*}{ Ціни продукції } & \multicolumn{6}{|c|}{ Роки } & \multicolumn{2}{|c|}{$\begin{array}{c}2015 \text { рік у \% } \\
\text { до: }\end{array}$} & \multicolumn{2}{|c|}{$\begin{array}{c}\text { У \% до цін бо- } \\
\text { рошна }\end{array}$} \\
\hline & 2010 & 2011 & 2012 & 2013 & 2014 & 2015 & 2010 & 2014 & 2010 p. & $2015 p$. \\
\hline 1. Пшениця яра & 1198 & 1433 & 1509 & 1572 & 1980 & 2604 & 217,3 & 131,5 & 61,3 & 64,0 \\
\hline $\begin{array}{l}\text { 1.1. Індекс иін, у \% } \\
\text { до минулого року }\end{array}$ & $X$ & 119,6 & 105,4 & 104,1 & 126,0 & 131,5 & $X$ & $X$ & $X$ & $X$ \\
\hline $\begin{array}{l}\text { 2. Борошно пше- } \\
\text { ничне }\end{array}$ & 1955 & 2248 & 2359 & 2507 & 2814 & 4070 & 208,2 & 144,6 & 100 & 100 \\
\hline $\begin{array}{l}\text { 2.1. Індекс иін, у \% } \\
\text { до минулого року }\end{array}$ & $X$ & 115,0 & 104,9 & 106,3 & 112,2 & 144,6 & $X$ & $X$ & $X$ & $X$ \\
\hline $\begin{array}{l}\text { 3. Макаронні ви- } \\
\text { роби }\end{array}$ & 4188 & 4758 & 4778 & 5099 & 5486 & 7916 & 189,0 & 144,3 & 214,3 & 194,5 \\
\hline $\begin{array}{l}\text { 3.1. Індекс иін, у \% } \\
\text { до минулого року }\end{array}$ & $X$ & 113,6 & 100,4 & 106,7 & 107,6 & 144,3 & $X$ & $X$ & $X$ & $X$ \\
\hline $\begin{array}{l}\text { 4. Хліб пшенич- } \\
\text { ний }\end{array}$ & 3275 & 3731 & 3925 & 4223 & 4702 & 7338 & 224,0 & 156,1 & 167,6 & 180,3 \\
\hline $\begin{array}{l}\text { 4.1. Індекс иін, у \% } \\
\text { до минулого року }\end{array}$ & $X$ & 113,9 & 105,2 & 107,6 & 111,4 & 156,1 & $\mathrm{X}$ & $\mathrm{X}$ & $\mathrm{X}$ & $\mathrm{X}$ \\
\hline $\begin{array}{l}\text { 5. Печиво солодке } \\
\text { i вафлі }\end{array}$ & 10445 & 11918 & 12240 & 12878 & 14567 & 21899 & 209,6 & 150,3 & 318,9 & 298,4 \\
\hline $\begin{array}{l}\text { 5.1. 4.1. Індекс иін, } \\
\text { у\% до минулого } \\
\text { року }\end{array}$ & $X$ & 114,1 & 102,7 & 105,2 & 113,1 & 150,3 & $\mathrm{X}$ & $\mathrm{X}$ & $\mathrm{X}$ & $\mathrm{X}$ \\
\hline
\end{tabular}

*Розраховано автором за даними Державної служби статистики України $[11,12]$

Дані таблиці 1 показують, що ціна пшеничного борошна знаходиться в прямій залежності від вартості пшениці, частка якої у структурі борошняного виробництва займає 75-80 \%. Так, у 2013-2015 pp. приріст середніх цін пшениці на 4,1 \%, 26 \% і 31,5\% обумовив приріст вартості пшеничного борошна на $6,3 \%, 12,2 \%$ і 44,6 \% відповідно. При цьому у системі вертикально суміжних ринків просліджується така закономірність (за винятком 2015 р.): у міру збільшення ступеню переробки продукції темпи приросту iii цін знижуються, тобто темп приросту цін борошна (або хлібопродуктів) є нижчим відповідного показника для нижньосуміжних ринків пшениці (або борошна). Так, у 2014 р. порівняно $з 2013$ р. приріст цін пшениці, борошна, макаронних виробів, хліба та печива склав, відповідно, $26 \%, 12,2 \%, 7,6 \%, 11,4 \%$ і 13,1 (див. табл. 1). Загалом темпи приросту цін на хлібобулочні та борошняні кондитерські вироби $є$ дещо вищими аналогічного показника для макаронних виробів; їх рівень наближається до рівня цінового приросту борошна.

Співвідношення цін хлібопродуктів до рівня цін на основну сировину (борошно пшеничне) за
2010-2015 рр. змінилося. Якщо в 2010 р. ціна макаронних виробів, хліба та печива перевищувала вартість борошна на $114,3 \%, 67,6 \%$ і $218,9 \%$, то в 2015 р. - на 94,5 \%, 80,3 \% і 198,4 \% відповідно.

Безумовно, коливання цін борошна обумовлює коригування цін хлібопродуктів, оскільки питома вага витрат на пшеничне борошно в собівартості хлібобулочної продукції складає більше $30 \%$, макаронів більше 50 \% в залежності від технології виробництва. Водночас ступінь впливу головного чинника (ціни борошна) щорічно знижується за рахунок динамічного зростання вартості енергоресурсів у структурі собівартості хлібопродуктів. Тобто підвищується частка товарів і послуг пов'язаних ринків у формуванні кінцевої ціни хлібопродуктів, зростає залежність стратегічних хлібних ринків від цінових тенденцій пов'язаних ринків енергоресурсів. Цю залежність доцільно враховувати в ході державного цінового регулювання даних ринків.

Для аналізу цінових співвідношень у зовнішньому вимірі (див. рис. 3) автором запропоновано використання коефічієнтів дискримінаціийності иін (внутрішніх і експортних), які дозволяють визначити 
глибину цінових різниць, динаміку та закономірності їх часових змін. Результати проведених розрахунків коефіцієнтів дискримінаційності експортних цін хлібопродуктів (табл. 2) свідчать про перевищення рівня імпортних цін над експортними в середньому по товарній групі 19 в 1,722 рази. У 2015 р. найглибша цінова різниця притаманна товарній групі 1901 «Готові харчові продукти з борошна, крупки, крупів»2,288 пункти. Для макаронних, хлібобулочних і борошняних кондитерських виробів коефіцієнт дискримінаційності експортних цін склав, відповідно, 1,872 і 1,728 пункти, та має тенденцію до зростання.

Таблиця 2

Динаміка коефіцієнтів дискримінаційності експортних цін хлібопродуктів *

\begin{tabular}{|l|c|c|c|c|c|c|c|c|}
\hline \multirow{2}{*}{ Товарні групи за УКТЗЕД } & \multicolumn{9}{|c|}{ Роки } & \multicolumn{2}{|c|}{$\begin{array}{c}\text { Динаміка змін } \\
\text { (+,- }\end{array}$} \\
\cline { 2 - 11 } & 2010 & 2011 & 2012 & 2013 & 2014 & 2015 & $(6-1)$ & $(6-5)$ \\
\hline \multicolumn{1}{|c|}{$\boldsymbol{1}$} & $\mathbf{2}$ & $\mathbf{3}$ & $\mathbf{4}$ & $\mathbf{5}$ & $\mathbf{6}$ & $\mathbf{7}$ & $\mathbf{8}$ \\
\hline $\begin{array}{l}\text { 1901. Готові харчові продукти з боро- } \\
\text { шна, крупки, крупів }\end{array}$ & 2,618 & 2,398 & 2,811 & 3,004 & 2,204 & 2,288 & $-0,329$ & $+0,085$ \\
\hline $\begin{array}{l}\text { 1902. Вироби з макаронного тіста ва- } \\
\text { рені або неварені, начинені або не на- } \\
\text { чинені }\end{array}$ & 1,312 & 1,363 & 1,456 & 1,483 & 1,453 & 1,872 & $+0,560$ & $+0,419$ \\
\hline $\begin{array}{l}\text { 1904. Готові харчові вироби, одержані } \\
\text { шляхом здуття або смаження зернових } \\
\text { культур (пластівці) }\end{array}$ & 1,459 & 1,395 & 0,961 & 1,074 & 0,992 & 0,998 & $-0,461$ & $+0,005$ \\
\hline $\begin{array}{l}1905 . \text { Хлібобулочні, борошняні конди- } \\
\text { терські вироби }\end{array}$ & 1,804 & 1,806 & 1,680 & 1,669 & 1,688 & 1,728 & $-0,076$ & $+0,040$ \\
\hline $\mathbf{У ~ с е р е д н ь о м у ~ п о ~ г р у п і ~ 1 9 ~}$ & $\mathbf{1 , 7 9 8}$ & $\mathbf{1 , 7 4 1}$ & $\mathbf{1 , 7 2 7}$ & $\mathbf{1 , 8 0 8}$ & $\mathbf{1 , 5 8 4}$ & $\mathbf{1 , 7 2 2}$ & $\mathbf{- 0 , 0 7 6}$ & $\mathbf{0 , 1 3 7}$ \\
\hline
\end{tabular}

"Розраховано автором за даними Державної служби статистики України $[11,12]$.

Дослідження системи вертикально суміжних ринків передбачає розрахунок та порівняльний аналіз коефіцієнтів дискримінаційності цін за усіма етапами логістичного ланцюга з метою визначення латентних цінових співвідношень, які необхідно враховувати в ході прийняття ефективних управлінських рішень. За результатами попередніх досліджень [8, с. 225-228] встановлено таку закономірність: у міру поглиблення ступеню переробки зерна коефіцієнти дискримінаційності експортних цін товарів знижуються (зокрема, 3 3,844 пунктів для пшениці до 1,854 пункти для пшеничного борошна й 1,728 пункти для хлібобулочних й кондитерських виробів у 2015 р.). Така закономірність є свідченням більш високого рівня ціновоі інтегрованості ринків продуктів переробки 3 високою доданою вартістю порівняно 3 ринками сировини. Оскільки ціна $є$ індикатором ринкової інтеграції [6], запропоновані нами коефіцієнти дискримінаційності цін (внутрішніх та експортних) можуть бути використані для оцінки рівня інтегрованості товарних ринків (на основі «закону єдиної ціни» [6]) у внутрі- шньому та зовнішньому вимірах та аналізу динаміки конвергенції цін. Так, значення коефіцієнтів дискримінаційності експортних цін хлібопродуктів за 20102015 рр. є свідченням хвилеподібної динаміки конвергенції цін з іiі зменшенням у 2013 та 2015 роки (див. табл. 2). Загалом у логістичному ланцюзі «пшениця борошно - хлібопродукти» рівень цінової конвергенції зростає, цінові різниці між експортними й імпортними цінами зменшуються, інтегрованість товарних ринків зростає.

Аналіз показників цінової еластичності попиту запропоновано розділити на дві складові (внутрішню та зовнішню) 3 метою більш об'єктивного визначення різноманітних станів попиту, що обумовлюють багатоваріантність управлінських рішень, які розробляються на основі ЦМ (див. рис. 3). Контурний аналіз ступеня чутливості внутрішнього та зовнішнього попиту до ціни проведемо на прикладі українського ринку макаронних виробів (табл. 3).

Таблиця 3

Розрахунок цінової еластичності внутрішнього та зовнішнього попиту на макаронні вироби в Україні"

\begin{tabular}{|l|c|c|c|c|c|c|c|}
\hline \multicolumn{1}{|c|}{ ПОКАЗНИКИ } & \multicolumn{7}{|c|}{ Роки } \\
\cline { 2 - 8 } & 2010 & 2011 & 2012 & 2013 & 2014 & 2015 & $2016^{* *}$ \\
\hline $\begin{array}{l}\text { 1. Обсяги попиту, тис. т, всього, } \\
\text { у тому числі: }\end{array}$ & 201,91 & 225,44 & 224,96 & 227,69 & 221,21 & 202,87 & 198,46 \\
\hline 1.1. Внутрішній попит & 189,87 & 208,96 & 202,92 & 201,75 & 196,49 & 179,39 & 174,36 \\
\hline 1.2. Зовнішній попит (експорт) & 12,04 & 16,48 & 22,03 & 25,93 & 24,71 & 23,49 & 24,10 \\
\hline
\end{tabular}


Продовження табл.3

\begin{tabular}{|l|c|c|c|c|c|c|c|}
\hline \multirow{2}{*}{ ПОКАЗНИКИ } & \multicolumn{7}{c|}{ Роки } \\
\cline { 2 - 9 } & 2010 & 2011 & 2012 & 2013 & 2014 & 2015 & 2016 \\
\hline 2. Зміна обсягів попиту, \%, у т.ч.: & $\mathrm{X}$ & 11,66 & $-0,22$ & 1,21 & $-2,85$ & $-8,29$ & $-2,17$ \\
\hline 2.1. Внутрішнього попиту ,\% & $\mathrm{X}$ & 10,05 & $-2,89$ & $-0,58$ & $-2,61$ & $-8,71$ & $-2,80$ \\
\hline 2.2. Зовнішнього попиту, \% & $\mathrm{X}$ & 36,89 & 33,67 & 17,70 & $-4,71$ & $-4,96$ & 2,62 \\
\hline 3. Зміна внутрішніх цін, \% & $\mathrm{X}$ & 13,60 & 0,43 & 6,70 & 7,59 & 44,31 & 39,73 \\
\hline 4. Зміна експортних цін, \% & $\mathrm{X}$ & 26,77 & 2,02 & 4,31 & $-3,74$ & $-31,43$ & 36,25 \\
\hline 5. Зміна доходів населення, \% & $\mathrm{X}$ & 15,49 & 11,45 & 10,25 & 3,75 & 1,42 & 1,90 \\
\hline $\begin{array}{l}\text { 6.Модуль коефіціснта цінової } \\
\text { еластичності попиту (2/3) }\end{array}$ & $\mathrm{X}$ & 0,857 & 0,505 & 0,181 & 0,375 & 0,187 & 0,055 \\
\hline 6.1. Внутрішнього попиту (2.1/3) & $\mathrm{X}$ & 0,739 & 6,752 & 0,086 & 0,344 & 0,196 & 0,070 \\
\hline 6.2. Зовнішнього попиту (2.2/4) & $\mathrm{X}$ & 1,378 & 16,642 & 4,102 & 1,258 & 0,158 & 0,072 \\
\hline $\begin{array}{l}\text { 7. Коефіцієнт еластичності попи- } \\
\text { ту населення за доходами (2.1/5) }\end{array}$ & $\mathrm{X}$ & 0,649 & $-0,252$ & $-0,056$ & $-0,696$ & $-6,120$ & $-1,472$ \\
\hline
\end{tabular}

* Розраховано автором за даними Державної служби статистики України $[11,12]$

*** Прогнозні значення

За період 2011-2016 рр. внутрішній попит на макаронну продукцію $є$ нееластичним (за винятком 2012 р.), зовнішній попит, навпаки, є еластичним (за винятком 2015-2016 рр.). Слід відзначити, що зовнішній попит на зерно та продукти його переробки $\epsilon$ еластичним [8, с. 235-236], що дозволяє державі моделювати структуру агропродовольчого експорту шляхом розробки та впровадження механізмів стимулювання експорту зерно- і хлібопродуктів із високою доданою вартістю. Споживчий попит населення на макаронні вироби нееластичний як за ціною, так i доходами; приріст доходів супроводжується зниженням обсягів споживання, що призводить до від'ємного значення коефіцієнта еластичності попиту споживачів за доходами.

Динаміку коефіцієнтів цінової еластичності попиту на макаронні вироби можна розділити на два часові періоди (рис. 4): (1) 2011-2013 рр. із середніми значення показників еластичності внутрішнього й зовнішнього попиту в 2,526 і 7,374 пункти; (2) 20142016 pp. із середніми значеннями показників в 0,204 і 0,496 пункти відповідно. Причиною різкого скорочення рівнів цінової еластичності товару у другому періоді $\epsilon$ значно більша відсоткова зміна його цін (внутрішніх і експортних) порівняно зі змінами обсягів попиту (див.табл. 3).

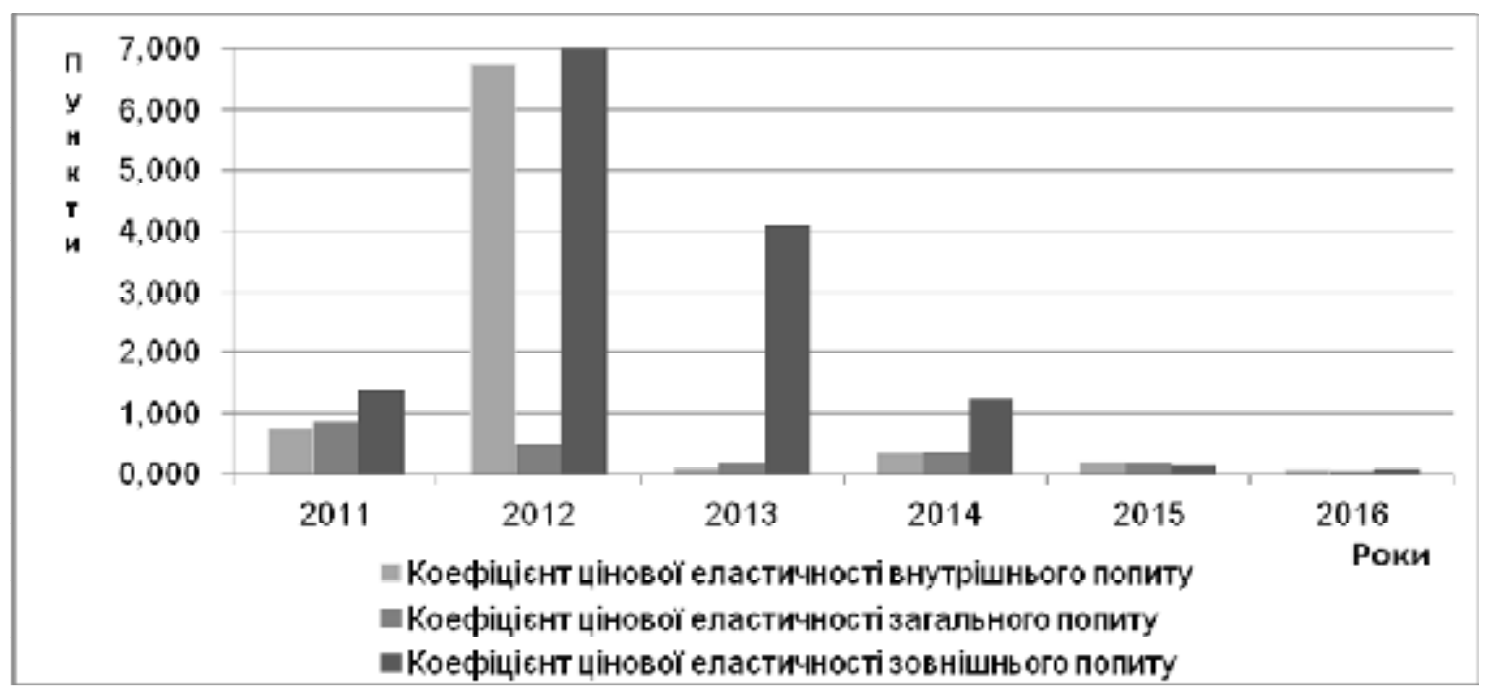

Рис. 4. Динаміка коефіціснтів цінової еластичності попиту на макаронні вироби в Україні*

*Побудовано автором за даними табл. 3 
ЦМ системи вертикально суміжних ринків передбачає розрахунок та порівняльний аналіз коефіцієнтів еластичності попиту за етапами логістичного ланцюга «пшениця - борошно - хлібопродукти», що дозволяє визначити певні особливості та пропорції в співвідношенні показників на суміжних ринках. Проведені дослідження довели існування багаторівневості в формуванні показників цінової еластичності у логістичних ланцюгах, дозволили ідентифікувати сектори інтегрованих ринків зернопродуктів за рівнем еластичності i, враховуючи ії природу та властивості, визначити вектори регуляторних заходів держави [8, с. 235-237]. Такий підхід покликаний забезпечити високу регуляторну еластичність секторів інтегрованого товарного ринку, тобто їх здатність продуктивно реагувати на зовнішній вплив та сприяти досягненню цільових показників державних заходів [8, с. 230].
Для аналізу цінової еластичності попиту запропоновано використання коефіuієнту перехресної еластичності попиту, який визначає ступінь зміни величини попиту на один товар, викликану зміною ціни на інший товар. Проведені розрахунки перехресної еластичності попиту на макаронні вироби (за ціною картоплі та овочів) довели, що дані товари $є$ комплементами, тобто при зниженні цін на картоплю та овочі попит на макаронні вироби зменшується, i навпаки (таблиця 4). Водночас позитивні значення коефіцієнтів перехресної еластичності попиту в 2010 і 2012 роках обумовлені значними змінами цін, які входять до складу обмежень використання даного показника (як відомо, його можна використовувати для визначення ефекту замінювання або доповнення товарів тільки при невеликих змінах цін [4]).

Розрахунок перехресної еластичності попиту на макаронні вироби в Україні *

Таблиця 4

\begin{tabular}{|l|c|c|c|c|c|c|c|}
\hline \multicolumn{2}{|c|}{ Показники } & \multicolumn{7}{c|}{ Роки } \\
\cline { 2 - 8 } & 2010 & 2011 & 2012 & 2013 & 2014 & 2015 & 2016 \\
\hline $\begin{array}{l}\text { 1. Зміна обсягів внутрішнього по- } \\
\text { питу макаронних виробів, \% }\end{array}$ & 3,66 & 10,05 & $-2,89$ & $-0,58$ & $-2,61$ & $-8,71$ & $-2,80$ \\
\hline 2. Зміна цін картоплі, \% & 64,10 & $-4,61$ & $-43,94$ & 63,29 & 16,80 & 12,09 & 9,95 \\
\hline 3. Зміна цін овочів, \% & $\mathrm{X}$ & $-16,17$ & $-8,53$ & 20,31 & 6,81 & 55,25 & 20,65 \\
\hline $\begin{array}{l}\text { 4. Коефіцієнт перехресної еластич- } \\
\text { ності макаронних виробів за ціною } \\
\text { картоплі (1/2) }\end{array}$ & 0,057 & $-2,182$ & 0,066 & $-0,009$ & $-0,155$ & $-0,720$ & $-0,282$ \\
\hline $\begin{array}{l}\text { 5. Коефіцієнт перехресної еластич- } \\
\text { ності макаронних виробів за ціною } \\
\text { овочів (1/3) }\end{array}$ & $\mathrm{X}$ & $-0,62$ & 0,34 & $-0,03$ & $-0,38$ & $-0,16$ & $-0,14$ \\
\hline
\end{tabular}

*Розраховано автором за даними Державної служби статистики України [11, 12]

Динаміку коефіцієнтів перехресної еластичності попиту на макаронні вироби можна розділити на два часові періоди (рис. 5): (1) 2011-2013 рр., період значних коливань; (2) 2014-2016 рр., період стабі- лізації із середніми значення показників перехресної еластичності (за ціною картоплі та овочів) -0,386 і 0,225 пункти відповідно.

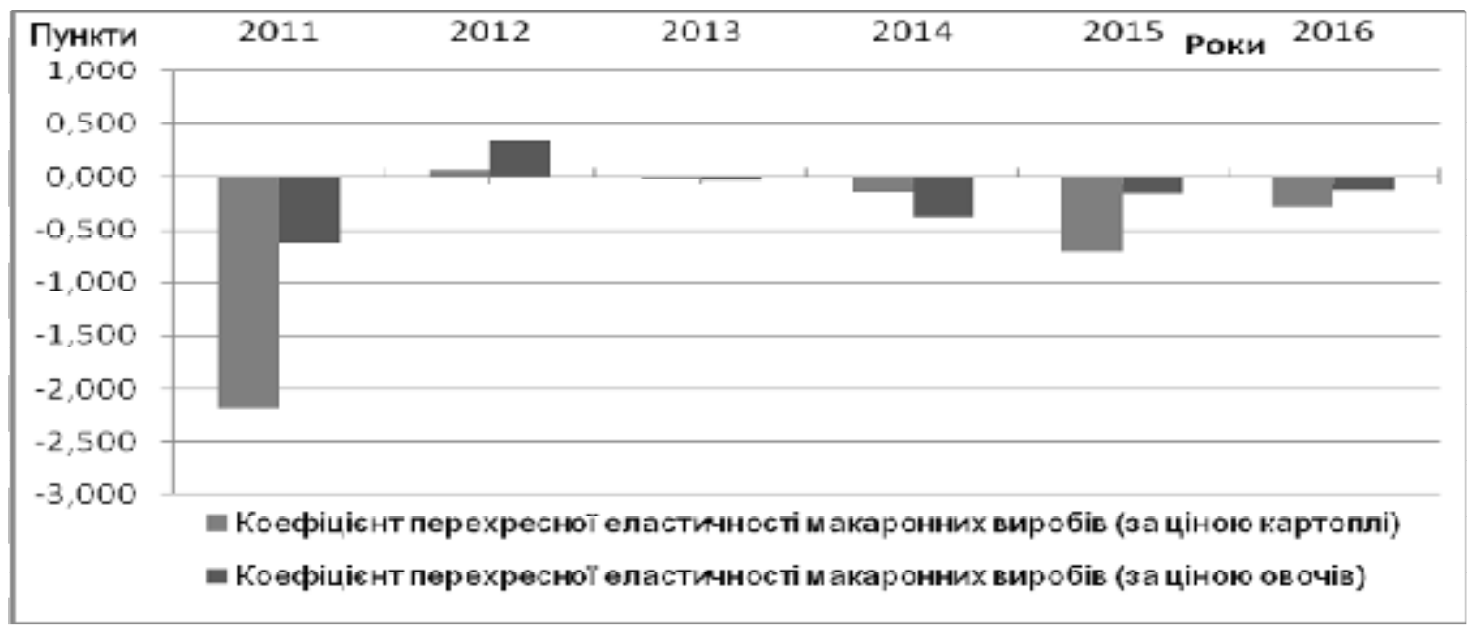

Рис. 5. Динаміка коефіцієнтів перехресної еластичності попиту на макаронні вироби в Україні"

*Побудовано автором за даними табл. 4 
На практиці проявом дії концепції перехресної еластичності попиту $є$ зменшення споживання населенням макаронних виробів влітку через зниження цін овочевої продукції й зростання весною в період високої вартості овочів [13]. Концепція еластичності попиту має важливе практичне значення, оскільки впливає на формування та обгрунтування цінової політики підприємства [14]. Водночас їі можна використовувати не тільки на мікро, але й макрорівні в ході обгрунтування (коригування) заходів державного цінового регулювання для узгодження економічних інтересів виробників та споживачів соціально значимої продукції. Певним обмеженням для більш широкого використання показників цінової еластичності попиту у ЦМ товарних ринків $є$ недостатність статистичних даних та необхідність формування інформаційної підсистеми моніторингу з використанням різних аналітичних джерел, що підвищує трудомісткість і вартість такого аналізу. Однак його результати, як показав контурний аналіз, дозволяють визначити латентні закономірності та співвідношення в системі вертикально суміжних ринків, що залишаються непоміченими, відтак, неврахованими в ході цінового регулювання.

Четвертий напрям ЦМ товарного ринку аналіз впливу державного цінового регулювання детально розглянутий автором у монографії [8]. У даній праці також проведено цінову діагностику ринків зерна та продуктів його переробки, обгрунтовано заходи селективного державного регулювання та здійснено оцінку їх ефективності, тобто проведені емпіричні дослідження засвідчили практичне застосування складових авторського методичного підходу до ЦМ товарного ринку (див. рис. 3).

Висновки та перспективи подальших досліджень. Ціновий моніторинг інтерпретовано як систему збору даних і аналізу цінових показників релевантного та вертикально суміжних до нього ринків, яка формує аналітичний фундамент для обгрунтування напрямів, методів і заходів державного селективного регулювання. Запропонований автором методологічний підхід до ЦМ товарного ринку об'єднав концептуальний базис як сукупність цілей, завдань i принципів моніторингу та методичний базис як суку- пність методичних підходів до ЦМ, методів державного регулювання та методичних положень щодо оцінки його ефективності. Акцентовано увагу на циклічності процесу ЦМ, представленим «колообігом» шістьох складових, та їх змінності в залежності від завдань моніторингу, активній участі держави в ньому шляхом коригування заходів для забезпечення їх ефективності.

Складовими ЦМ є інформаційна, методична, організаційна та технічна підсистеми. У дослідженні сфокусовано увагу на методичній підсистемі, зокрема, іiї оціночній компоненті. За результатами проведених емпіричних досліджень автором виділено чотири напрями ЦМ товарного ринку, а саме: (1) аналіз цінової динаміки; (2) аналіз цінових співвідношень; (3) аналіз показників цінової еластичності; (4) аналіз впливу державного цінового регулювання на процеси відтворення ринку. Для кожного напряму обгрунтовано специфічні складові та множина цінових показників, як широко поширених, так й інноваційних, а також методики цінового аналізу.

Деякі напрями моніторингу апробовано в ході контурного ЦМ українського ринку хлібопродуктів, що дозволило, по-перше, довести практичну значимість авторського методичного підходу, і по-друге, визначити низку латентних закономірностей і цінових співвідношень у системі вертикально суміжних ринків, які доцільно врахувати в ході обгрунтування напрямів цінової політики держави та ії заходів у ринковому вимірі. Наукова новизна проведеного дослідження полягає в удосконаленні теоретикометодичних положень цінового моніторингу товарного ринку, які базуються на множині наукових принципів, розширеній оціночній основі з використанням системи різноякісних прикладних показників, що всебічно охоплюють цінові характеристики ринків за етапами логістичного ланцюга, а також орієнтовані на механізми державного селективного регулювання. Перспективи подальших досліджень полягають у розширенні складових ЦМ товарних ринків, розробці нових аналітичних показників та методик цінового аналізу, а також їх апробації на прикладі стратегічних товарних ринків для підтвердження емпіричної результативності.

\section{Література}

1. Бутенко А. И. Конъюнктура рынка / А. И. Бутенко, В. Р. Кучеренко, В. А. Карпов. - Одесса: Феникс, 1998. - $190 \mathrm{c}$.

2. Державна політика фінансової підтримки розвитку аграрного сектору АПК: [монографія] / За ред. М. Я. Дем’яненка. - К.: ННЦ Інститут аграрної економіки, 2011. - 372 с.

3. Ринки реального сектора економіки України: структурно-інституціональний аналіз / За ред. В. О. Точиліна; НАН України; Ін-т екон. та прогнозув. - К.: Фенікс, 2009. - 640 с.

4. Павленко А.Ф. Маркетингова цінова політика: [монографія] / А. Ф. Павленко, В. Л. Корінєв. - К.: КНЕУ, 2004. - 332 c.

5. Савицкая Г.В. Анализ хозяйственной деятельности предприятия / Г.В. Савицкая. - [7-е изд., испр.]. - Минск: ООО «Новое знание», 2002. - 703 с.

6. Gluschenko, K.P. (2010). Spatial integration of commodity markets: the basics. Retrieved from http://www.econom.nsu.ru/staff/chair_et/gluschenko/Teaching/Papers/1-2.pdf.38

7. Румянцева Е. Е. Новая экономическая энциклопедия / Е. Е. Румянцева. - М.: ИНФРА-М, 2005. - VI, $724 \mathrm{c}$. 
8. Нікішина О. В. Механізми регулювання інтегрованого зернового ринку: [монографія] / О. В. Нікішина. - Одеса: ІПРЕЕД НАН України, 2014. - 450 с.

9. Нікішина О. В. Методичні засади критеріальної оцінки відтворювальних процесів на інтегрованому зерновому ринку України / О. В. Нікішина // Економіка: реалії часу. - 2014. - №2 (12). - С.139-149.

10. Nikishyna, O. V. (2014). Criterion of Value Added in Assessing Efficiency of Integrated Markets Grain and Products his Processing in Ukraine. Nauka i Studia, 20 (130), 52 - 57.

11. Статистичний щорічник України за 2015 рік / За ред. I.М. Жук. - К.: Державна служба статистики України, 2016. - 574 с.

12. Офіційний сайт Державної служби статистики України. [Електронний ресурс] - Режим доступу: //http://www.ukrstat.gov.ua/

13. Booth O.(2010). Overview market of macaroni products. World products, 2 (61), 5-7.

14. Dovga, T. A. (2015). Practical use of elasticity demand concept when substantiating enterprise's pricing policy. Retrieved from http://feu.kneu.edu.ua/ua/confere nce/conf_social_dev_ukr_12/section3/dovga/.

Стаття надійшла 12.01.2017

Стаття прийнята до друку 26.01.2017

Доступно в мережі Internet 31.03.2017

\author{
Никишина О.В. \\ доктор экономических наук, старший научный сотрудник \\ отдел рыночных механизмов и структур \\ Институт проблем рынка и экономико-экологических исследований НАН Украины \\ Французский бульвар, 29, г. Одесса, Украина, 65044 \\ E-mail: ksenkych@gmail.com
}

\title{
МЕТОДИЧЕСКИЙ ПОДХОД К ЦЕНОВОМУ МОНИТОРИНГУ ТОВАРНОГО РЫНКА (НА ПРИМЕРЕ РЫНКА ХЛЕБОПРОДУКТОВ)
}

Ценовой мониторинг является составляющей общего мониторинга товарного рынка. Ценовой мониторинг - это система сбора данных и анализа ценовых показателей релевантного и вертикально смежных рынков, которая позволяет постоянно фиксировать и анализировать ценовые характеристики рынков. Она формирует аналитическую базу для обоснования направлений, методов и мер государственного селективного регулирования. Система ценового мониторинга имеет циклическую природу и включает четыре подсистемы: информационную, методическую, организационную и техническую.

В статье обоснован методологический подход к ценовому мониторингу товарного рынка, объединивший концептуальный и методический базисы. В качестве главных принципов ценового мониторинга автором выделены следующие: (1) приоритетность экономических интересов государства; (2) системность и комплексность; (3) оперативность и гибкость; (4) объективность и точность; (5) эфрфективность; (6) целенаправленность; (7) научность. Данные принципы ориентируют вектор мониторинга на оценку ценовой ситуации с позиции эффективного функционирования товарного рынка и реализации экономических интересов государства на рынке.

Разработанный методический подход включает четыре основных направления ценового мониторинга товарного рынка, а именно: (1) анализ ценовой динамики; (2) анализ ценовых соотношений; (3) анализ показателей ценовой эластичности; (4) анализ влияния государственного ценового регулирования на процессы воспроизводства. Для каждого направления обоснованы специфические составляющие и множество ценовых показателей, как известных, так и инновационных, а также методики ценового анализа.

Проведенный контурный ценовой мониторинг украинского рынка хлебопродуктов по направлениям, имеющим инновационную направленность, позволил определить ряд закономерностей и ценовых соотношений. Так, по результатам анализа установлено, что в логистической цепи «пшеница мука - хлебопродукты» по мере увеличения степени переработки продукции темпы прироста ее внутренних цен снижаются, уровень ценовой конвергенции растет, разницы между экспортными и импортными ценами уменьшаются, ценовая интегрированность товарных рынков растет. Учет таких латентных тенденций в практике государственного управления ориентирован на повышение эффективности селективных регуляторных мер.

Ключевые слова: ценовой мониторинг и анализ, вертикально смежные рынки, логистическая цепь, рынок хлебопродуктов, селективные регуляторные меры. 


\author{
Nikishina 0. \\ Doctor of Economics, Senior Researcher \\ Department of market mechanisms and structures \\ Institute of market problems and economic \& ecological research \\ of National Academy of Sciences of Ukraine \\ Frantsuzskiy boulevard, 29, Odessa, Ukraine, 65044 \\ E-mail:ksenkych@gmail.com
}

\title{
METHODICAL APPROACH TO PRICE MONITORING OF COMMODITY MARKET (FOR EXAMPLE, MARKET OF BREAD PRODUCTS)
}

Price monitoring is a component of overall monitoring of the commodity market. Price monitoring is a system of collecting data and analysis of price indices of relevant and vertically adjacent markets, which allows you to continuously fix and analyze price characteristics markets. It forms the analytical base for grounding of directions, methods and measures of state selective regulation. The system of price monitoring has a cyclical nature and consists of four subsystems: informational, methodological, organizational and technical.

In the article justified methodological approach to price monitoring of commodity market, which combined the conceptual and methodical bases has been substantiated. As main principles of price monitoring the author highlighted the following: (1) priority of economic interests of the state; (2) systematization and complexity; (3) efficiency and flexibility; (4) objectivity and accuracy; (5) effectiveness; (6) purposefulness; (7) scientific character. These principles direct vector monitoring to assessment of price situation from the perspective of effective functioning of the commodity market and implementation of economic interests of the state in the market.

The developed methodical approach includes four main directions of price monitoring of commodity market, namely: (1) analysis of price dynamics; (2) analysis of price ratios; (3) analysis of indices of price elasticity; (4) analysis of impact of state price regulation in the processes of reproduction. For each direction specific components and a majority of price indices, both known and innovative, as well as price analysis methodology have been substantiated.

The conducted contoured price monitoring of Ukrainian market of bread products on the directions that have innovative orientation, allowed to determine a number of regularities and price ratios. So, by results of the analysis it was found that, in the logistics chain «wheat - flour - bread products» with increasing the degree of processing product, the growth rate of domestic prices are falling, the level of price convergence is increasing, differences between prices of export and import decrease, pricing integration of commodity markets is growing. Accounting for these latent tendencies in the practice of public administration is focused on improving the efficiency of selective regulatory measures.

Keywords: price monitoring and analysis, vertically adjacent markets, logistics chain, market of bread products, selective regulatory measures.

\section{References}

1. Butenko, A. Y. (1998). Konъiunktura runka . Odessa: Fenyks.

2. Dem'ianenko, M. Ia. (2011). Derzhavna polityka finansovoi pidtrymky rozvytku ahrarnoho sektoru APK: K.: NNTs Instytut ahrarnoi ekonomiky.

K.: Feniks.

3. Tochylina, V. O. (2009). Rynky realnoho sektora ekonomiky Ukrainy: strukturno-instytutsionalnyi analiz.

4. Pavlenko, A.F. (2004). Marketynhova tsinova polityka. K.: KNEU.

5. Savytskaia , H. V. (2002). Analyz khoziaistvennoi deiatelnosty predpryiatyia . Mynsk: OOO «Novoe znanye».

6. Gluschenko, K. P. Spatial integration of commodity markets: the basics. . Retrieved February, 2017, from http://www.econom.nsu.ru/staff/chair et/gluschenko/Teaching/Papers/1-2.pdf.38

7. Rumiantseva, E. E. (2006). Novaia эkonomycheskaia эntsyklopedyia (Vol. 6). M.: YNFRA-M.

8. Nikishyna, O. V. (2014). Mekhanizmy rehuliuvannia intehrovanoho zernovoho rynku. Odesa. IPREED NAN Ukrainy.

9. Nikishyna, O. V. (2014). Metodychni zasady kryterialnoi otsinky vidtvoriuvalnykh protsesiv na intehrovanomu zernovomu rynku Ukrainy . Ekonomika: realii chasu, 2(12), 139-149.

10. Nikishyna, O. V. (2014). Criterion of Value Added in Assessing Efficiency of Integrated Markets Grain and Products his Processing in Ukraine. Nauka i Studia, 20(130), 52-57. Ukrainy.

11. Zhuk, I. M. (2016). Statystychnyi shchorichnyk Ukrainy za 2015 rik . K.: Derzhavna sluzhba statystyky

12. Ofitsiinyi sait Derzhavnoi sluzhby statystyky Ukrainy. (n.d.). Retrieved February, 2017, from //http://www.ukrstat.gov.ua/

13. Booth, O. (2010). Overview market of macaroni products. World products (61st ed., Vol. 2), 5-7.

14. Dovga, T. A. (2015). Practical use of elasticity demand concept when substantiating enterprise's pricing

policy. Retrieved February, 2017, from http://feu.kneu.edu.ua/ua/confere nce/conf_social_dev_ukr_12/section3/dovga/. 